This is the peer reviewed version of J ay, Chantelle, Fitzgerald, J ean, Hipps, Neil and Atkinson, Christopher (2015) Why short-term biochar application has no yield benefits; evidence from three field-grown crops. Soil Use and Management, 31 (2). pp. 241-250, which has been published in final form at http://dx.doi.org/10.1111/sum.12181. This article may be used for non-commercial purposes in accordance with Wiley Terms and Conditions for SelfArchiving.

Soil Use and Management

\title{
Why short-term biochar application has no yield benefits; evidence from three field-grown crops
}

\author{
Chantelle N. Jay ${ }^{1}$, Jean D. Fitzgerald ${ }^{1}$, Neil A. Hipps ${ }^{1}$, Christopher J. Atkinson ${ }^{1,2, *}$ \\ ${ }^{1}$ East Malling Research, New Road, East Malling, Kent, ME19 6BJ, UK and ${ }^{2}$ Natural Resources \\ Institute, University of Greenwich, Central Avenue, Chatham Maritime \\ Kent, ME4 4TB, UK
}

Correspondence: C.J. Atkinson. E-mail c.j.atkinson@gre.ac.uk Tel.:+44(0)1634 883634 (C.J. Atkinson)

Chantelle.jay@emr.ac.uk (C.N. Jay), Jean.fitzgerald@emr.ac.uk (J.D. Fitzgerald), n.a.hipps@kent.ac.uk (N.A. Hipps)

Running title: Biochar effects on crop yields 


\section{Abstract}

This study determines the impact of biochar, as a supplement, on soil nutrient availability and yields for three crops within commercial management systems in a temperate environment. Central to the suggestion of biochar benefits is an increase in soil nutrient availability and here we test this idea by examining crop nutrient uptake, growth and yields of field-grown spring barley, strawberry and potato. Biochar produced from Castanea sativa wood, was incorporated into a sandy loam soil at 0 , 20 and $50 \mathrm{t} \mathrm{ha}^{-1}$ as a supplement to standard crop management practice. Fertiliser was applied normally for each of the three crops. The biochar contained substantial concentrations of $\mathrm{Ca}, \mathrm{Mg}, \mathrm{K}, \mathrm{P}$, but only $\mathrm{K}$ occurred at high concentration in water soluble analysis. The large concentration of extractable $\mathrm{K}$ resulted in a significant increase of extractable $\mathrm{K}$ in soil. The increased availability of $\mathrm{K}$ in biochar-treated soil, with the exception of spring barley grain and the leaves of strawberry during the second year, did not induce greater tissue concentrations. In general, biochar application rate had little influence on the tissue concentration of any nutrient, irrespective of crop or sampling date. There was, however, evidence of a biocharinduced increase in tissue Mo and a decrease in Mn, in strawberry, which could be linked to soil alkalinisation as could the reduction in extractable soil P. These experiments show a single rotational application of biochar to soil had no effect on the growth or harvest yield of any of these field-grown crops. Heavy metal analysis revealed small concentrations in the biochar (i.e. $<10 \mu \mathrm{g} \mathrm{g}^{-1}$ biochar), with the largest levels for $\mathrm{Ni}, \mathrm{V}$ and $\mathrm{Cu}$. 
Keywords: Biochar, harvest yield, soil, nutrients, Hordeum vulgare, Fragaria $X$ ananassa, Solanum tuberosum

\section{Introduction}

Biochar is produced by heating plant biomass in the absence of oxygen (pyrolysis). Its production and incorporation into soils is a novel process for establishing a long-term sink for $\mathrm{CO}_{2}$ storage, with limited risk of atmospheric return (Lehmann et al., 2005). There exists within the Brazilian Amazon extensive patches of anthropogenically derived 'fertile' soils (terra preta). These patches show alterations in native soil variables, such as soil nutrient content, alkalinisation of the soil solution (Gundale \& DeLuca, 2007; Scott et al., 2014). Total soil nutrient concentrations can be 3 to 5 -fold greater relative to the surrounding infertile soil with increased nutrient availability (Glaser et al., 2001). An increase in soil nutrients provides a mechanism by which terra preta patches enhanced crop production (Lehmann et al., 2005). It is unclear if the terra preta phenomenon is a feature unique to impoverished tropical soils and their climates or if these potential agricultural benefits can be acquired in temperate climates and soils (Atkinson et al., 2010; Scott et al., 2014). Some biochar experiments, outside the tropics, show increased yields and reduced nutrient leaching, but these increased yields and improved soil fertility responses are not always evident (Major et al., 2009; Van Zwieten et al., 2010). Attempts to understand how fertility increases, including biochar enhancements of nutrient bioavailability and reduced ion mobility, have been suggested (Warnock et al., 2007; Atkinson et al., 2010). Changes in soil chemistry are implicated, with alterations in microbial diversity and activity, with porosity in biochar particles acting as refuges for soil organisms, e.g. 
mycorrhizal fungi (Spokas et al., 2012; Reverchon et al., 2014). Given that biochar has the potential for use in the northern hemisphere to sequester atmospheric carbon in soils, it is less clear if it increases soil fertility, particularly in fertile soils already well managed (see the meta-analysis of Jeffery et al., 2011 and Crane-Droesch et al., 2013).

Here we determine whether sequestering carbon into the soil as biochar influences harvest yield within commercial cropping systems. Specifically we determine how biochar application to a temperate soil, used within current commercial crop management systems for three field-grown crops, changes nutrient availability and crop uptake. Our hypothesis is that if biochar enhanced crop yields are predominantly achieved via enhanced availability of soil nutrients, then application to temperate agriculture soils should only show benefits when these soils are nutrient deficient.

To achieve this, we have carried out a field experiment, which includes the evaluation, separately, of spring barley, strawberry and potato. Standard commercial growing practices, growing cycles and crop management approaches were used throughout with limited management changes due to biochar incorporation. Data were collected over the normal commercial cropping season and rotational cycles, i.e. barley and potato are one-year rotation crops, whereas a June-bearing strawberry crop has a 2-year cycle.

\section{Materials and methods}

\section{Biochar production and analyses}

Biochar was produced from predominantly sweet chestnut (Castanea sativa) [and species Acer, Fraxinus, Fagus and Quercus] by slow pyrolysis in a metal ring kiln 
over 24 hours, with a maximal temperature between 350 to $400^{\circ} \mathrm{C}$. The charcoal was crushed and sieved to particle size between 1 to $6 \mathrm{~mm}$ (diam). Prior to incorporation, the biochar was analysed using a dry-ashing method after heated acid digestion in aqua regia ( $\mathrm{HCl}$ and $\mathrm{HNO}_{3}$ in a 3:1 ratio) (CLARRC, University of Edinburgh, UK). Elemental concentrations were measured by ICPOE spectrometry (analytical standards from Fisher Scientific, Loughborough, UK). Cation exchange capacity (CEC) was measured according to BS 7755-3.3:1995 (using barium chloride solution). Moisture content was determined thermogravimetrically using a method for chemical analysis of wood charcoal (ASTM D1762-84, 2007) (using loss of weight on drying at $\left.105^{\circ} \mathrm{C}\right)$. Carbon, $\mathrm{H}, \mathrm{O}, \mathrm{N}$ and $\mathrm{S}$ were analysed using an elemental analyser (CLARRC, University of Edinburgh, UK). Soil extractable nutrients were measured according to MAFF RB 427 (1986) and MAFF RB 209 (1994) protocols (using KCl for $\mathrm{N}$ extraction and $\mathrm{KHCO}_{3}$ for $\mathrm{P}$ and $\mathrm{NH}_{4} \mathrm{NO}_{3}$ for the remainder) (Lancrop Laboratories, Pocklington, UK). Water-soluble extraction was analysed (BS EN 13652, 2001 (including aqua regia soluble elements) and BS EN 13040, 2000) using a sample weight equivalent to 60 to $300 \mathrm{~cm}^{3}$ volume of water (NRM Laboratories, Bracknell, UK).

\section{Experimental}

Experiments were carried out at East Malling Research, UK (51 $\left.17^{\circ} \mathrm{N}, 00^{\circ} 27^{\prime} \mathrm{E}\right)$. The soil was a mixture of the Malling and Barming series, with a sandy clay loam topsoil overlying clay subsoil on ragstone (Jarvis et al., 1984). The soil is well drained with an available water holding class between 150 - >200 mm to $1000 \mathrm{~mm}$ depth (Fordham and Green, 1980). Three experiments were set up using spring barley (Hordeum vulgare L. cv. Westminster), strawberry (Fragaria x ananassa Duch. cv Elsanta) and 
potato (Solanum tuberosum L. cv. Maris Piper). The three treatments were soil biochar incorporation at $0 \mathrm{t} \mathrm{ha}^{-1}$ dry weight biochar (control); $20 \mathrm{t} \mathrm{ha}^{-1}$ dry weight biochar (low) and $50 \mathrm{t} \mathrm{ha}^{-1}$ dry weight biochar (high). Variability was reduced by locating the experiments in the same field, adjacent to each other. Biochar was incorporation within the rooting zone of an individual crop.

Spring barley (Hordeum vulgare). Plots were within a commercial field planting with individual plots $1.5 \mathrm{~m}$ wide x $2 \mathrm{~m}$ long. Weighed amounts of biochar were distributed on the soil surface and mechanically incorporated to a depth of 5-10 cm with a rotary tiller (tractor mounted rotary disc incorporation unit) before sowing in April. Most adventious roots occur in the top $10 \mathrm{~cm}$. Seed was drilled to a depth of $3 \mathrm{~cm}$ in rows $12.5 \mathrm{~cm}$ apart at a sowing rate of $157 \mathrm{~kg} \mathrm{ha}^{-1}$. A minimum of 2 rows at the outer edge of each plot were used as guard rows. The crop received $81 \mathrm{~kg} \mathrm{~N} \mathrm{ha}^{-1}$ as 'Nitro-Chalk' (ammonium nitrate-calcium carbonate mixture, 27\% N) broadcast in early May.

Strawberry (Fragaria x ananassa). The experimental plots were raised beds (1.2 m wide x 6 m long) under a polytunnel. Prior to planting, in April, biochar was incorporated manually to a depth of $10 \mathrm{~cm}$ and the bed surface covered with polythene mulch. Each plot consisted of 20 plants, planted at $60 \mathrm{~cm}$ within the row and $30 \mathrm{~cm}$ between rows. Plants were fertigated (drip irrigation and fertiliser) initially throughout June until mid-August with $25 \mathrm{~kg} \mathrm{ha}^{-1}$ of Ferticare ${ }^{\mathrm{TM}}$ (NPK ratio of 12:1.3:31.5, Yara Ltd, UK) followed by $25 \mathrm{~kg} \mathrm{ha}^{-1}$ of Ferticare ${ }^{\mathrm{TM}}$ (NPK ratio of 21:3.1:17.4) until the end of August. In year two, the 'main season crop', Ferticare ${ }^{\mathrm{TM}}$ was used at $25 \mathrm{~kg} \mathrm{ha}^{-1}$ with an NPK ratio of 22:1.7:18.2 or an NPK ratio of 12:2.6:29.9 containing $\mathrm{MgO}\left(\mathrm{Mg}\right.$ at $6 \mathrm{mg} \mathrm{litre}^{-1}$ ). Fertiliser was applied weekly from late May until mid-September. 
Potato (Solanum tuberosum) Plots were $6 \mathrm{~m}$ long and each contained 3 ridges, $0.8 \mathrm{~m}$ apart. A guard ridge was used between parallel plots. Biochar was incorporated manually to a minimum depth of $10 \mathrm{~cm}$ in early May. Graded (35-55 mm) seed potatoes were hand planted at $30 \mathrm{~cm}$ intervals. The crop received $1850 \mathrm{~kg} \mathrm{ha}^{-1}$ of Ferticare $^{\mathrm{TM}}$ with an NPK ratio of 13:5.7:17.4 in early May. After shoot emergence, the crop was drip-line irrigated. Two weeks before harvest the crop was desiccated with Challenge ${ }^{\circledR}$ SC, aclonifen $600 \mathrm{~g} \mathrm{l}^{-1}$ (Bayer Crop Science, UK).

Soil analysis. Soil samples were taken using a gouge auger (diameter $2.5 \mathrm{~cm}$ ) to the depth of the biochar incorporation and crop rooting depth, i.e. 0 to $8 \mathrm{~cm}$ in the spring barley and 8 to $12 \mathrm{~cm}$ for the strawberry and potato experiments. Each sample consisted of three soil cores per plot. At the beginning of June, soil pH was measured after mixing in $\mathrm{dH}_{2} \mathrm{O}(2.5 \mathrm{x} \mathrm{v} / \mathrm{v})$ and shaking for 30 mins (MAFF RB 427, 1986). After harvest, in September for the barley and strawberry experiments, and at the end of September for potato experiment, soil samples were taken for analysis of available nutrients (S, P, K, Mg, Mn, B, Cu) and pH (MAFF RB 427, 1986) (Lancrop Laboratories, Pocklington, UK). Strawberry plants were also cropped in year two (commercial practice) and soil extractable nutrients and $\mathrm{pH}$ were analysed in May and after final harvest in August.

Spring barley plant growth, yield and grain quality. The numbers of barley shoots within three $1 \mathrm{~m}$ rows per plot were counted in mid-May to determine emergence. Shoot extension measurements were taken using labelled shoots from three plants per plot, during June and early July. Shoot dry weight and the main stems and tiller 
number per plant were determined pre-harvest by removing $1 \mathrm{~m}$ length of 1 row per plot at ground level in mid-August. Weights were determined after heating in a forced draft oven for $48 \mathrm{~h}$ at $80^{\circ} \mathrm{C}$. Harvesting was in August, cutting five $1 \mathrm{~m}$ rows in each plot. Grain number of 50 main stem ears was determined per plot. Main stem and tiller ears were threshed separately for each plot using a small plot thresher. The one thousand grain weight (TGW) was determined for main stem and tiller ears (a mean of 540 grains per sample) after using a MARVIN digital seed counter (Hoopman, The Netherlands). Grain moisture content was determined (Grainmaster, Protimeter, UK).

Strawberry leaf growth, yield and fruit quality. Leaf growth was repeatedly measured, by labelling a newly emerged middle trifoliate leaflet from mid-June on three plants per plot. Three plants per plot were cut at ground level in August, and separated into flower pedicles, rhizomes plus leaves and 'crowns'. Samples were oven dried for $48 \mathrm{~h}$ at $80^{\circ} \mathrm{C}$. Ripe fruits were picked twice weekly from June through July from 12 central plants per plot and yield and quality (size) measurements made. Fruit were size graded (>35 mm, 25-35 mm, <25 mm, misshapen fruit and damaged fruit), counted and weighed in both years.

For chemical analysis, in year 1, three fruit samples were taken per plot, in midJuly, frozen in liquid nitrogen and stored at $-80^{\circ} \mathrm{C}$. Fruit acids were analysed by HPLC using a Waters 2690 separation module (Waters Ltd, UK). Sweetness (Brix) measurements were taken on three 'primary' fruits per plot on four picking dates in July. Brix measurements were taken with a digital refractometer (Atago Palette Series PR-32 $\alpha$, Japan). These fruit were also used for firmness measurements using an LRX Penetrometer (Lloyd instruments, UK) and averaged. The above analyses were 
repeated, in July of year two. Measurements of fruit sweetness and firmness were made in June and July.

Potato shoot growth, yield and tuber quality. Leaf growth was measured by labelling, repeatedly, newly emerged leaf on three plants per plot. Measurements were taken from June to August along with plant heights. All tubers from ten adjacent plants, from each plot, were harvested in September. Tubers were sized (45-65 mm, 65-85 mm, $>85 \mathrm{~mm}$ ) with tubers $<45 \mathrm{~mm}$ classed as waste. Damaged or diseased tubers were analysed separately. Each size tuber category was weighed (fresh weight) and counted. Six class 1 tubers per plot (3 from each of the $45-65 \mathrm{~mm}$ and $65-85 \mathrm{~mm}$ categories) were analysed for firmness, using a $1 \mathrm{~cm}$ longitudinal tuber strip, using a penetrometer (HPE II Fff version, Heinrich Bareiss, Germany). Tuber dry matter content was assessed, sampling as above, with the fresh weight of 6 tuber slices recorded before oven drying at $80^{\circ} \mathrm{C}$ for 1 week.

Crop nutrient analysis. A 200 g sample grain from main stem ears of barley was analysed from each plot. For strawberry, 30 fully expanded leaves were collected per plot in June and July in year 1, and May and August in year two and the leaves dried for $48 \mathrm{~h}$ at $80^{\circ} \mathrm{C}$. Potato tubers were peeled and cut longitudinally combining six halves from each plot for analysis. Nitrogen, P, K, Mg, S, Ca, B, Fe, Zn, Mn and Cu concentrations were determined for grain, leaf and tuber samples using perchloric/nitric acid digests and ICPOE spectroscopy (MAFF RB 427, 1986). Spring barley grains and strawberry leaves were analysed by Lancrop Laboratories (Pocklington, UK) and tubers by NRM laboratories (Berkshire, UK). 
Statistical analyses. Data were analysed using analysis of variance (ANOVA) (Genstat for Windows VSN International, 2011) using a Latin Rectangle design. Analysis of Covariance (ANCOVA) was used to determine the dose response trend lines for data in Figures 1 and 2 and Table 2 using R (R Development Core Team, 2008). Separate models were fitted for each crop. Average concentrations for each nutrient in the control (no biochar) plots were calculated separately for each crop, and used as an index to determine the percentage change in the nutrient titres for the 20 and $50 \mathrm{t} \mathrm{ha}^{-1}$ biochar treatments. A linear ANCOVA model was fitted for each crop, with nutrient as a factor and biochar concentration as the covariate. Regression slopes from these models were tested for statistically significant deviations from zero using t-tests (Figure 2). Each soil nutrient the $0 \mathrm{t} \mathrm{ha}^{-1}$ biochar treatment is shown at a baseline of 100 on the $y$ axis with the variability presented for all treatments.

\section{Results}

\section{Biochar chemical analysis}

Total concentrations of $\mathrm{N}, \mathrm{Ca}, \mathrm{Fe}, \mathrm{Mg}, \mathrm{K}$ and $\mathrm{Na}$ are shown in Table 1 . The most readily extractable or soluble nutrient was $\mathrm{K}$ and the $\mathrm{pH}$ in water was 9.0-9.2. Moisture content at application was 20.2\%. Cation exchange capacity (CEC) was high at $87 \mathrm{cmol} \mathrm{kg}^{-1} . \mathrm{V}, \mathrm{Ni}, \mathrm{Cu}$ had the highest concentrations (approximately 7-10 $\mu \mathrm{g} \mathrm{g}^{-1}$ ) of heavy metals (see supporting information), concentrations of $\mathrm{Ni}, \mathrm{Cr}, \mathrm{Pb}, \mathrm{As}, \mathrm{Hg}$ and Cd were negligible.

\section{Soil chemical analysis and $p H$}

Soil extractable K, Mg, and B concentrations were significantly increased following biochar application, irrespective of crop (Figure 1, Table 2). These effects were still 
detectable in the strawberry experiment, in year two (391 days after incorporation, see supporting information). At the same time the concentration of soil extractable $\mathrm{P}$ declined for all crops. Biochar had no effect on the concentrations of extractable S, $\mathrm{Mn}$ or $\mathrm{Cu}$. Soil $\mathrm{pH}$ was significantly more alkaline with increasing rates of biochar irrespective of crop (Figure 2).

\section{Crop tissue nutrient analysis}

There were few changes in tissue nutrient concentrations. However, K concentration in barley grains from the highest biochar rate was significantly greater (5742, 5977 and $6194 \mu \mathrm{g} \mathrm{g}^{-1}, p=0.04$, SED 142, $d f$ 8) in the $0,20,50 \mathrm{t} \mathrm{ha}^{-1}$ biochar treatments respectively (see supporting information). The decline in the N:S grain ratio (18.7, 18.3 and 17.5 ) was significant ( $p=0.04$ SED $0.37, d f$ ) with increasing biochar (see supplementary data). There was no effect of biochar on $\mathrm{N}, \mathrm{Mg}, \mathrm{S}, \mathrm{Ca}$ and Fe concentrations in strawberry leaves, but P, B and Mo concentrations were greater 90 days (in July) after incorporation at the higher rate (Table 3). In cropping year 2 (391 and 461 days after incorporation) both biochar treatments increased leaf concentrations of $\mathrm{P}, \mathrm{B}, \mathrm{K}$, and Mo in leaves strawberry (Table 4). There were no significant effects of biochar on potato tuber nutrient concentrations at harvest (Table 5).

Spring barley plant growth, yield and grain quality

Biochar application did not significantly affect germination (22, 20 and 24 shoots per $1 \mathrm{~m}$ length of row for $0,20,50 \mathrm{t} \mathrm{ha} \mathrm{a}^{-1}$ biochar treatments respectively). Stem growth rate was greatest in mid-June averaging $3.4 \mathrm{~cm} \mathrm{~d}^{-1}$ declining to $0.6 \mathrm{~cm} \mathrm{~d}^{-1}$ in late-June and $0.1 \mathrm{~cm} \mathrm{~d}^{-1}$ in early-July; there were no treatment effects. Equally there were no 
cumulative treatment effects on total shoot dry matter prior to harvest or harvest grain yield (mean total grain weights 597, 579 and $558 \mathrm{~g} \mathrm{~m}^{-2}$ for the $0,20,50 \mathrm{t} \mathrm{ha}^{-1}$ biochar treatments respectively). Grain moisture content was $11.5 \%$ at harvest. No differences occurred in ear number per $\mathrm{m}^{2}$, the number of grains ear $^{-1}$, or the thousand-grain weight for the biochar treatments (see supporting information).

\section{Strawberry leaf growth, yield and fruit quality}

For all treatments, initial leaf growth was approximately $0.9 \mathrm{~cm} \mathrm{~d}^{-1}$ in mid-June declining to $0.35 \mathrm{~cm} \mathrm{~d}^{-1}$ in late-June and to $0.05 \mathrm{~cm} \mathrm{~d}^{-1}$ after final harvest (early July). Biochar had no effect on leaf growth rates, or total plant dry matter at harvest (121, 125 and $113 \mathrm{~g}$ DW) for the 0, 20 and $50 \mathrm{t} \mathrm{ha}^{-1}$ rates respectively. Fruit yields in year one and two were unaffected by treatment, irrespective of size class (Tables 6 and 7). In year one there was a significant effect of biochar reducing the weight of misshapen and damaged fruit. Fruit malic acid (1.50, 1.69 and $\left.1.87 \mathrm{mg} \mathrm{g}^{-1}\right)$ and sucrose (21, 20 and $23 \mathrm{mg} \mathrm{g}^{-1}$ ) concentrations were significantly ( $p=0.03$, SED 0.105, $d f \quad 8$ and $p=0.04$, SED 1.07, $d f 8$ respectively) higher with increasing biochar treatments (see supporting information). There were no effects on organic acids, or on fructose or glucose concentration, or the overall sugar: acid ratio of either year. Brix values increased in fruit during the harvest period in both years but without treatment effects. Fruit firmness, in June declined from 19.4 to $17.4 \mathrm{~N}$ with biochar rate of application $(p=0.032$, SED 0.63), this effect was lost in July.

\section{Potato shoot growth, yield and tuber quality}

Biochar had no effect on shoot height, leaf growth rate $\left(4.4,4.3\right.$ and $4.6 \mathrm{~cm} \mathrm{~d}^{-1}$ between 18 to 29 June) or tuber yield. Mean number of class 1 tubers was $10.8,13.1$ 
and 10.9 plant $^{-1}$, and weighed 1.81, 2.14 and $1.85 \mathrm{~kg}(\mathrm{FW})$ for the 0,20 and $50 \mathrm{t} \mathrm{ha}^{-1}$ biochar treatments respectively (see supplementary data). Estimated yield of tubers hectare $^{-1}$ was $70.0,82.8$ and $71.6 \mathrm{t}$ for the 0,20 and $50 \mathrm{t} \mathrm{ha}^{-1}$ biochar rates respectively. There were no treatment effects on weight, or number of tubers in the waste category. Streptomyces scabies (common scab) infection increased ( $p=0.05$, SED 3.2, $d f$ 8) with biochar incorporation with 12,14 and 21 potatoes per 10 plants affected for the $0,20,50 \mathrm{t} \mathrm{ha}^{-1}$ treatments respectively (see supplementary data). There were no treatment effects on tuber firmness.

\section{Discussion}

Our hypothesis tests the assumption that biochar application to soil enhances crop growth and yield, and that this occurs through increased availability of beneficial soil nutrients. We tested this hypothesis in, temperate European commercial crop production, with a soil supplied with nutrients for optimal production. Results show that Castanea sativa biochar had little effect on the growth or yield of barley, strawberry or potato. This is in agreement with recently studies (Jeffery et al., 2011; Ippolito et al., 2012; Novak et al., 2014). The potential yields of the barley cultivar used average from 5 to $7 \mathrm{tha}^{-1}$ in the UK (limagrain.co.uk/springbarley), with our experiments yielding $6 \mathrm{t} \mathrm{ha}^{-1}$. Barley germination was not increased, even at a high biochar application rate $\left(<50 \mathrm{t} \mathrm{ha}^{-1}\right)$ as with wheat (Van Zweiten et al., 2010; Solaiman et al., 2012), but similarly for a range of biochar types, applied to maize, there was no effect (Free et al., 2010). Strawberry yields for one-year-old plants averaged $300 \mathrm{~g} \mathrm{plant}^{-1}$, which is normal, and two-year-old plants had commercial yields. The organoleptic (taste) experience was consistently the same despite small 
changes in fruit biochemical traits. Potato tuber yields were similar to commercial practice (i.e. $69 \mathrm{t} \mathrm{ha}^{-1}$ ).

Soil analysis showed biochar increased some soil nutrients (K, Mg and B), while others did not change, and $\mathrm{P}$ declined. The increase in these three soil extractable nutrients was rarely translated into differences in crop nutrient concentrations. The reason for the limited response to biochar is that the management of this soil ensured sufficient available nutrition to supply crop demand. The guidelines for their optimal tissue nutrient concentrations support this notion (Defra 2010). Crane-Droesch et al. (2013) concluded, from a number of studies, that biochar effects on growth were limited to the fertility of the soil to which it was applied. They showed that crops grown on soils with reduced soil CEC and organic carbon, responded more positively, with respect to yield increases on biochar application, whereas parameters associated with the biochar itself e.g. $\mathrm{pH}$, pyrolysis conditions, did not predict yield responses.

Increased soil extractable $\mathrm{K}$ with biochar incorporation is consistent with other work and has been linked with plant $\mathrm{K}$ uptake. Here, high concentrations of $\mathrm{K}$ in the biochar were readily extractable, with 17 and $43 \mathrm{~kg} \mathrm{ha}^{-1}$ extractable at the lower and higher biochar rates. Extractable $\mathrm{K}$ in the soil, in which potatoes were grown, was below that recommended for adequate growth (240 $\mathrm{mg} \mathrm{K} \mathrm{kg}^{-1}$ soil) and the additional $\mathrm{K}$ from the biochar increased the concentration in the tubers, suggesting biochar acted as a supplement to the standard fertiliser management. A similar effect was found for $\mathrm{K}$ in barley grains. Strawberry tissue K concentrations were unaffected due to the application of sufficient crop fertigation.

Soil extractable P from the control plots of strawberry showed concentrations of close to or exceeding upper recommendation (70 mg $\mathrm{P} \mathrm{kg}^{-1}$ soil) for optimal growth 
(Defra, 2010). Although soil extractable P declined with biochar application, this did not induce lower strawberry leaf $\mathrm{P}$ concentrations. This lack of response may be due to the confounding effect of the direct application of $\mathrm{P}$ to roots via fertigation. In the absence of additional soil applied P, biochar application has been shown to induce a short-term decline in $\mathrm{P}$ available directly after application (Nelson et al., 2011). Extractable biochar P measured here was low, equivalent to about $0.5 \mathrm{~kg}$ and $1.2 \mathrm{~kg}$ $\mathrm{ha}^{-1}$ for the 20 and $50 \mathrm{t} \mathrm{ha}^{-1}$ biochar rates, respectively. It is unlikely that direct release of $\mathrm{P}$ would have influenced concentrations found in the soil. Increasing soil $\mathrm{pH}(>7.5)$ may suppress the availability of $\mathrm{P}$ (and other nutrients including $\mathrm{B}, \mathrm{Mn}, \mathrm{Cu}$ and $\mathrm{Zn}$ ) and therefore biochar soil alkalinisation may explain the reduced extractable P. The Barming Series sandy loam experimental soil (Jarvis et al., 1984) was slightly acidic prior to biochar application, but within the acceptable range without the need for lime application. The fact that biochar application rapidly raised soil $\mathrm{pH}$, highlights the soil's limited buffering capacity and the importance of the $\mathrm{pH}$ link to nutrient availability when applying biochar to soil with low buffering capacity. The increase in $\mathrm{pH}$ was reflected by an increase in Mo and a reduction of Mn concentrations in strawberry leaves. Biochar may also influence bioavailability through surface sorption of chelating organic molecules, which can reduce or increase P solubility (De Luca et al., 2009).

There was no evidence that this biochar acted as a source of crop nitrogen. Application of 20 or $50 \mathrm{t} \mathrm{ha}^{-1}$ of biochar might add 64 and $160 \mathrm{t} \mathrm{ha}^{-1}$ of total $\mathrm{N}$ respectively to the soil, but little of this was water soluble or available to crops. Nutrient release characteristics of biochars are known to be slow; $\mathrm{N}$ release is about $<2 \mathrm{mg} \mathrm{kg}^{-1}$, compared to $\mathrm{P}$ availability, which is highly variable (15-11,000 mg kg-1) (Chan and $\mathrm{Xu}$, 2009). Field nitrogen release was not measured here, but assuming 
similar concentrations to those of Chan and Xu (2009), only $0.1 \mathrm{~kg} \mathrm{~N} \mathrm{ha}^{-1}$ would be available at $50 \mathrm{t} \mathrm{ha}^{-1}$ biochar. Additional crop nitrogen is frequently proposed as a key benefit of biochar application to soils, through soil nutrient status via $\mathrm{N}$ absorption, reduced N leaching and increased N use efficiency (Major, 2009). It also explains why terra preta patches, when compared with deficient tropical soils, show large positive short-term impacts on crop growth (Spokas et al., 2012; Biedermann and Harpole, 2013; Crane-Droesch et al., 2013). Our experiments show within these commercial cropping systems biochar provides no nitrogen benefits.

\section{Conclusions}

Three different field grown crops show that biochar incorporation, into fertile soil, had no short-term crop growth effects. Biochar did increase soil $\mathrm{pH}$ and the concentration of $\mathrm{B}, \mathrm{K}$ and $\mathrm{Mg}$ and this was linked to an increase in crop uptake. There was no evidence of changes in crop yield or quality. The short time frame of this study may limit the expression of potential biochar benefits, or those caused by repeated biochar applications. Potentially biochar toxic metal contamination was within acceptable guidelines. The absence of yield promotion is linked to soil fertility status and supports the notion that well managed fertile temperate soils will have limited response to biochar.

\section{Acknowledgements}

The work was funded by the East Malling Trust. We thank the East Malling farm and Rothamsted for equipment loan and Drs Gillian Arnold and Stephan Young for statistical input. 
Supporting information associated with this article can be found, in the online version, at htt://

\section{References}

ASTM D1762-84 2007. Standard Test Method for Chemical Analysis of Wood Charcoal. ASTM International, West Conshohocken, PA, USA.

Atkinson, C.J., Fitzgerald, J.D., \& Hipps, N.A., 2010. Potential mechanisms for achieving agricultural benefits from biochar application to temperate soils: A review. Plant Soil 337, 1-18.

Biederman, L.A., \& Harpole, S.W., 2013. Biochar and its effects on plant productivity and nutrient cycling: a meta- analysis. Global Change Biology Bioenergy 5, 202-214.

BS EN 13040, 2000. Soil improvers and growing media. Sample preparation for chemical and physical tests, determination of dry matter content, moisture content and laboratory compacted bulk density BSI, London, UK ISBN 0580 34252218 pp.

BS EN 13652, 2001. Soil improvers and growing media. Extraction of water soluble nutrients and elements BSI, London, UK ISBN 058038267218 pp.

BS 7755-3.3:1995., 1995. Soil quality. Chemical methods. Determination of effective cation exchange capacity and base saturation level using barium chloride solution. BSI, London, UK ISBN 058023568864 pp.

Chan, K.Y., \& Xu Z., 2009. Biochar; nutrient properties and their enhancement. Chapter 5. In: Lehmann J, Joseph S (eds) Biochar for environmental management science and technology. Earthscan, London, pp 67-84. 
Crane-Droesch, A., Abiven, S., Jeffery, S., \& Torn, M.S., 2013. Heterogeneous global crop yield response to biochar: a meta-regression analysis. Environment Research Letters 8, 44-49.

Defra, 2010. Fertiliser Manual (RB209). TSO, Norwich, UK pp 252

DeLuca, T.H., MacKenzie, M.D., \& Gundale, M.J., 2009. Bio-char effects on soil nutrient transformation. In: Lehmann J, Joseph, S (eds) Biochar for environmental management science and technology. Earthscan, London, pp 251-270.

Fordham, S.J., \& Green, R.D., 1980. Soils of Kent, Soil Survey Bulletin No. 9. The Soil Survey, Rothamsted Experimental Station, Harpenden, Hertfordshire, UK.

Free, H.F., McGill, C.R., Rowarth, J.S., \& Hedley, M.J., 2010. The effect of biochars on maize (Zea mays) germination. New Zealand Journal Agricultural Research 53, 1-4.

Glaser, B., Guggenberger, G., \& Zech, W., 2001. Black carbon in sustainable soils of the Brazilian Amazon region. In: Swift RS, Spark KM (eds) Understanding and managing organic matter in soils, sediments and waters. International Humic Substances Society, St Paul, MN, pp 359-364.

Gundale, M.J., \& DeLuca, T.H., 2007. Charcoal effects on soil solution chemistry and growth of Koeleria macrantha in the ponderosa pine/Douglas-fir ecosystem. Biology Fertility of Soils 43, 303-311.

Ippolito J.A., Laird D.A., \& Busscher W.J., 2012. Environmental benefits of biochar. Journal of Environmental Quality 41:967-972.

Jarvis, M.G., Allen, R.H., Fordham, S.J., Hazelden, J., Moffat, A.J., \& Sturdy, R.G., 1984. Soil survey of England and Wales Bulletin No 15. Lawes Agricultural Trust, Harpenden, Herts. UK. 
Jeffery, S., Verheijen, F.G.A., van der Velde. M., \& Bastos, A.C., 2011. A quantitative review of the effects of biochar application to soils on crop productivity using meta-analysis. Agriculture, Ecosystems and Environment 144, 175-187.

Lehmann, J., Gaunt, J., \& Rondon, M., 2005. Biochar sequestration in terrestrial ecosystems - a review. Mitigation and Adaptation Strategies for Global Change 11, 403-427.

MAFF (Ministry of Agriculture Fisheries and Food), 1986. The analysis of agricultural materials Reference Book 427, HMSO London. 248.

MAFF (Ministry of Agriculture Fisheries and Food), 1994. Fertiliser Recommendations for Agricultural and Horticultural Crops Reference Book 209 (England, Wales and Northern Ireland) (6th Edition), HMSO London, ISBN 0112429351.

Major, J., Steiner, C., Downie, A., \& Lehmann, J., 2009. Biochar effects on nutrient leaching. Chapter 15, In: Lehmann J, Joseph S (eds) Biochar for environmental management science and technology. Earthscan, London pp 271-287.

Nelson, N.O., Agudelo, S.C., Yuan, W., \& Gan, J., 2011. Nitrogen and phosphorus availability in biochar-amended soils. Soil Science 17, 218-226.

Novak J.M., Spokas K. A., Cantrell K. B., Ro K. S., Watts D. W., Glazer B., Busscher W. J. \& Hunt P. G.

2014. Effects of biochars and hydrochars produced from lignocellulosic and animal manure on fertility of a Mollisol and Entisol. Soil Use and Management, 30, $175-181$. 
R Development Core Team (2008) R: A language and environment for statistical computing. R Foundation for Statistical Computing, Vienna, Austria

Reverchon, F., Flicker, R.C., Yang, H., Yan, G., Xu, Z., Chen, C., Hosseini Bai, S., \& Zhang, D., 2014. Changes in $\delta^{15} \mathrm{~N}$ in a soil-plant system under different biochar feedstocks and application rates. Biology and Fertility of Soils 50, 275-283.

Scott H.L., Ponsonby D., \& Atkinson C.J. (2014) Biochar: an improver of nutrient and soil water availability - what is the evidence. CAB Reviews 9, 019.

Solaiman, Z.M., Murphy, D.V., \& Abbott, L.K. 2012. Biochars influence seed germination and early growth of seedlings. Plant and Soil 353, 273-287.

Spokas, K.A., Cantrell, K.B., Novak, J.M., Archer, D.W., Ippolito, J.A., Collins, H.P., Boateng A.A., Lima I.M., Lamb M.C., McAloon A.J., Lentz R.D. \& Nichols K.A., 2012. Biochar: A synthesis of its agronomic impact beyond carbon sequestration. Journal of Environmental Quality 41, 973-987.

Van Zweiten, L., Kimber, S., Morris, S., Chan, K.Y., Downie, A., Rust, J., Joseph, S., \& Cowie, A., 2010. Effects of biochar from slow pyrolysis of papermill waste on agronomic performance and soil fertility. Plant and Soil 327, 235-246.

VSN International, 2011. GenStat for Windows $14^{\text {th }}$ Edition. VSN International, Hemel Hempstead, UK. Web page: GenStat. Co. UK.

Warnock, D.D., Lehmann, J., Kuyper, T.W., \& Rillig, M.C., 2007. Mycorrhizal responses to biochar in soil - concepts and mechanisms. Plant Soil 300, 9-20. 
Table 1 Chemical analysis of slow pyrolysis biochar produced from feedstock predominately derived from Castanea sativa (European sweet chestnut)

\begin{tabular}{lccc}
\hline Element & $\begin{array}{c}\text { Total } \\
\text { analysis }^{a} \\
\left(\mathrm{cg} \mathrm{g}^{-1}\right)\end{array}$ & $\begin{array}{c}\text { Soil } \\
\text { extractable }^{b} \\
\left(\mu \mathrm{g} \mathrm{g}^{-1}\right)\end{array}$ & $\begin{array}{c}\text { Water } \\
\text { soluble }^{c} \\
\left(\mu \mathrm{g} \mathrm{g}^{-1}\right)\end{array}$ \\
\hline $\mathrm{C}$ & 65.5 & & \\
$\mathrm{O}$ & 32.9 & & \\
$\mathrm{H}$ & 1.29 & & 10.1 \\
$\mathrm{~N}$ & 0.32 & 10 & $43.1^{*}$ \\
$\mathrm{~S}$ (as sulphate*) & 0.02 & $\left(\mu \mathrm{g} \mathrm{g}^{-1}\right)$ & $\left(\mu \mathrm{g} \mathrm{g}^{-1}\right)$ \\
& $\left(\mu \mathrm{g} \mathrm{g}^{-1}\right)$ & 24 & 5 \\
$\mathrm{P}$ & 1200 & 856 & 225 \\
$\mathrm{~K}$ & 1416 & & 9.3 \\
$\mathrm{Ca}$ & 19673 & 282 & 4.2 \\
$\mathrm{Mg}$ & 1899 & & 3.03 \\
$\mathrm{Fe}$ & 3491 & 78 & 0.16 \\
$\mathrm{Mn}$ & 263 & 6.3 & 0.29 \\
$\mathrm{~B}$ & 10.4 & & 0.08 \\
$\mathrm{Zn}$ & 65.4 & & 15.7 \\
$\mathrm{Na}$ & 1066 & 3.3 & $<0.06$ \\
$\mathrm{Ba}$ & 84.0 & & \\
$\mathrm{Cu}$ & 7.4 & & \\
\hline
\end{tabular}

${ }^{a}$ Analysed by the Contaminated Land Assessment \& Remediation Research Centre, University of Edinburgh, UK

${ }^{b}$ Analysed by Lancrop Laboratories, Yara UK Limited, Pocklington, UK

${ }^{c}$ Analysed by NRM laboratories, Bracknell, Berkshire, UK 
Table 2 The effect of soil incorporation of biochar produced by slow pyrolysis of Castanea sativa at 0,20 and $50 \mathrm{t} \mathrm{ha}^{-1}$ on soil extractable nutrient concentrations ( $\mu \mathrm{g} \mathrm{g}^{-1}$ soil) in plots of barley cultivar Westminster, strawberry cultivar Elsanta and potato cultivar Maris Piper

\begin{tabular}{|c|c|c|c|c|}
\hline \multirow[b]{3}{*}{$P$} & \multirow{3}{*}{$\begin{array}{l}\text { No biochar } \\
79.2 \pm 1.68\end{array}$} & \multicolumn{3}{|c|}{ Average across all biochar application rates } \\
\hline & & Barley & Strawberry & Potato \\
\hline & & $79.2 \pm 2.44$ & $71.6 \pm 2.29$ & $78.3 \pm 3.49$ \\
\hline K & $119 \pm 6.3$ & \pm 5.7 & $104 \pm 9.4$ & \pm 10.4 \\
\hline Mg & $64.1 \pm 1.64$ & $69.5 \pm 1.08$ & $59.4 \pm 2.34$ & $68.0 \pm 2.46$ \\
\hline S & $11.6 \pm 1.59$ & $4.7 \pm 0.33$ & $14.8 \pm 2.68$ & $12.2 \pm 1.11$ \\
\hline B & $0.92 \pm 0.03$ & $0.97 \pm 0.03$ & $0.86 \pm 0.03$ & $1.0 \pm 0.06$ \\
\hline $\mathrm{Mn}$ & $162 \pm 6.71$ & $129 \pm 7.22$ & $187 \pm 5.8$ & \pm 9.3 \\
\hline $\mathrm{Cu}$ & $12.6 \pm 0.51$ & $15.7 \pm 1.14$ & $11.1 \pm 0.35$ & $12.7 \pm 0.24$ \\
\hline
\end{tabular}

Note: Analysis is shown is derived from ANOVA for the comparison of crops separately for differences in soil nutrients with and without biochar. As the analysis revealed few significant differences (except $K)$ the average for both biochar applications rates are shown. Analysis across all treatments showed correlation coefficients of 0.61 and 0.63 and $p<0.001$ for the negative trend for $P$ and the positive trend for $K$. 
Table 3 The effect of soil incorporation of biochar produced by slow pyrolysis of Castenea sativa at 0,20 or $50 \mathrm{t} \mathrm{ha}^{-1}$ on nutrient concentrations of fully expanded strawberry leaves from first year plants of the cultivar Elsanta measured in late June and July

\begin{tabular}{|c|c|c|c|c|c|}
\hline \multirow[b]{2}{*}{ Nutrient } & \multicolumn{3}{|c|}{ Amount of biochar $\left(\mathrm{t} \mathrm{ha}^{-1}\right)$} & \multirow{2}{*}{$p$} & \multirow{2}{*}{$\begin{array}{l}\text { s.e.d. } \\
\text { (8 d.f.) }\end{array}$} \\
\hline & 0 & 20 & 50 & & \\
\hline June & & & & \multirow{2}{*}{0.27} & \multirow{2}{*}{0.035} \\
\hline $\mathrm{N}\left(\mathrm{cg} \mathrm{g}^{-1}\right)$ & 2.91 & 2.87 & 2.93 & & \\
\hline$P\left(\mathrm{cg} \mathrm{g}^{-1}\right)$ & 0.28 & 0.28 & 0.28 & 0.98 & 0.018 \\
\hline$K\left(\mathrm{cg} \mathrm{g}^{-1}\right)$ & 2.26 & 2.25 & 2.23 & 0.93 & 0.066 \\
\hline $\operatorname{Mg}\left(\mathrm{cg} \mathrm{g}^{-1}\right)$ & 0.35 & 0.37 & 0.35 & 0.43 & 0.013 \\
\hline $\mathrm{S}\left(\mathrm{cg} \mathrm{g}^{-1}\right)$ & 0.10 & 0.10 & 0.98 & 0.87 & 0.004 \\
\hline $\mathrm{Ca}\left(\mathrm{cg} \mathrm{g}^{-1}\right)$ & 1.58 & 1.71 & 1.58 & 0.42 & 0.112 \\
\hline $\mathrm{B}\left(\mu \mathrm{g} \mathrm{g}^{-1}\right)$ & 47 & 53 & 52 & 0.15 & 2.9 \\
\hline $\mathrm{Fe}\left(\mu \mathrm{g} \mathrm{g}^{-1}\right)$ & 121 & 136 & 128 & 0.37 & 9.9 \\
\hline $\mathrm{Zn}\left(\mu \mathrm{g} \mathrm{g}^{-1}\right)$ & 27 & 28 & 24 & 0.04 & 1.2 \\
\hline $\operatorname{Mn}\left(\mu \mathrm{g} \mathrm{g}^{-1}\right)$ & 111 & 115 & 100 & 0.30 & 9.5 \\
\hline $\mathrm{Cu}\left(\mu \mathrm{g} \mathrm{g}^{-1}\right)$ & 6.00 & 5.95 & 5.60 & 0.131 & 0.189 \\
\hline $\operatorname{Mo}\left(\mu g^{-1}\right)$ & 0.36 & 0.43 & 0.53 & $<0.01$ & 0.034 \\
\hline July & & & & \multirow{2}{*}{0.51} & \multirow{2}{*}{0.032} \\
\hline $\mathrm{N}\left(\mathrm{cg} \mathrm{g}^{-1}\right)$ & 1.93 & 1.89 & 1.90 & & \\
\hline$P\left(\mathrm{cg} \mathrm{g}^{-1}\right)$ & 0.27 & 0.27 & 0.30 & 0.02 & 0.010 \\
\hline $\mathrm{K}\left(\mathrm{cg} \mathrm{g}^{-1}\right)$ & 1.66 & 1.69 & 1.73 & 0.37 & 0.046 \\
\hline $\mathrm{Mg}\left(\mathrm{cg} \mathrm{g}^{-1}\right)$ & 0.22 & 0.22 & 0.23 & 0.19 & 0.009 \\
\hline$S\left(\mathrm{cg} \mathrm{g}^{-1}\right)$ & 0.09 & 0.09 & 0.09 & 0.82 & 0.003 \\
\hline $\mathrm{Ca}\left(\mathrm{cg} \mathrm{g}^{-1}\right)$ & 0.76 & 0.79 & 0.84 & 0.52 & 0.069 \\
\hline $\mathrm{B}\left(\mu \mathrm{g} \mathrm{g}^{-1}\right)$ & 35 & 36 & 42 & 0.04 & 2.4 \\
\hline $\mathrm{Fe}\left(\mu \mathrm{g} \mathrm{g}^{-1}\right)$ & 78 & 77 & 81 & 0.47 & 2.8 \\
\hline $\mathrm{Zn}\left(\mu \mathrm{g} \mathrm{g}^{-1}\right)$ & 20 & 19 & 21 & 0.16 & 1.1 \\
\hline $\operatorname{Mn}\left(\mu \mathrm{g} \mathrm{g}^{-1}\right)$ & 93 & 86 & 83 & 0.21 & 4.8 \\
\hline $\mathrm{Cu}\left(\mu \mathrm{g} \mathrm{g}^{-1}\right)$ & 5.80 & 5.83 & 6.05 & 0.304 & 0.163 \\
\hline $\operatorname{Mo}\left(\mu \mathrm{g} \mathrm{g}^{-1}\right)$ & 0.43 & 0.54 & 0.57 & 0.03 & 0.045 \\
\hline
\end{tabular}

s.e.d. = standard error of difference between means

d.f. = degrees of freedom 
Table 4 The effect of soil incorporation of biochar produced by slow pyrolysis of Castenea sativa at 0,20 or $50 \mathrm{t} \mathrm{ha}^{-1}$ on nutrient concentrations of fully expanded strawberry leaves from second year plants of the cultivar Elsanta measured in late May and early August

\begin{tabular}{|c|c|c|c|c|c|}
\hline \multirow{2}{*}{ Nutrient } & \multicolumn{3}{|c|}{ Amount of biochar $\left(\mathrm{t} \mathrm{ha}^{-1}\right)$} & \multirow[b]{2}{*}{$p$} & \multirow{2}{*}{$\begin{array}{c}\text { s.e.d. } \\
\text { (8 d.f.) }\end{array}$} \\
\hline & 0 & 20 & 50 & & \\
\hline \multicolumn{6}{|l|}{ May } \\
\hline $\mathrm{N}\left(\mathrm{cg} \mathrm{g}^{-1}\right)$ & 2.25 & 2.25 & 2.30 & 0.685 & 0.067 \\
\hline$P\left(\mathrm{cg} \mathrm{g}^{-1}\right)$ & 0.28 & 0.30 & 0.31 & 0.037 & 0.007 \\
\hline $\mathrm{K}\left(\mathrm{cg} \mathrm{g}^{-1}\right)$ & 1.69 & 1.79 & 1.80 & 0.055 & 0.044 \\
\hline $\mathrm{Mg}\left(\mathrm{cg} \mathrm{g}^{-1}\right)$ & 0.24 & 0.24 & 0.24 & 0.576 & 0.006 \\
\hline$S\left(\mathrm{cg} \mathrm{g}^{-1}\right)$ & 0.08 & 0.09 & 0.09 & 0.090 & 0.004 \\
\hline $\mathrm{Ca}\left(\mathrm{cg} \mathrm{g}^{-1}\right)$ & 0.82 & 0.83 & 0.78 & 0.548 & 0.045 \\
\hline $\mathrm{B}\left(\mu \mathrm{g} \mathrm{g}^{-1}\right)$ & 29 & 34 & 35 & 0.006 & 1.3 \\
\hline $\mathrm{Fe}\left(\mu \mathrm{g} \mathrm{g}^{-1}\right)$ & 116 & 92 & 95 & 0.470 & 20.5 \\
\hline $\operatorname{Zn}\left(\mu \mathrm{g} \mathrm{g}^{-1}\right)$ & 19 & 18 & 18 & 0.153 & 0.4 \\
\hline $\operatorname{Mn}\left(\mu \mathrm{g} \mathrm{g}^{-1}\right)$ & 126 & 92 & 75 & 0.001 & 8.7 \\
\hline $\mathrm{Cu}\left(\mu \mathrm{g} \mathrm{g}^{-1}\right)$ & 5.52 & 5.78 & 6.15 & 0.003 & 0.124 \\
\hline $\operatorname{Mo}\left(\mu g^{-1}\right)$ & 0.30 & 0.35 & 0.42 & 0.022 & 0.035 \\
\hline \multicolumn{6}{|l|}{ August } \\
\hline $\mathrm{N}\left(\mathrm{cg} \mathrm{g}^{-1}\right)$ & 1.89 & 1.88 & 1.95 & 0.588 & 0.075 \\
\hline$P\left(\mathrm{cg} \mathrm{g}^{-1}\right)$ & 0.17 & 0.19 & 0.20 & 0.046 & 0.011 \\
\hline $\mathrm{K}\left(\mathrm{cg} \mathrm{g}^{-1}\right)$ & 1.04 & 1.10 & 1.17 & 0.060 & 0.043 \\
\hline $\mathrm{Mg}\left(\mathrm{cg} \mathrm{g}^{-1}\right)$ & 0.33 & 0.34 & 0.33 & 0.623 & 0.015 \\
\hline $\mathrm{S}\left(\mathrm{cg} \mathrm{g}^{-1}\right)$ & 0.07 & 0.07 & 0.07 & 0.234 & 0.003 \\
\hline $\mathrm{Ca}\left(\mathrm{cg} \mathrm{g}^{-1}\right)$ & 2.52 & 2.47 & 2.47 & 0.891 & 0.124 \\
\hline$B\left(\mu g g^{-1}\right)$ & 51 & 53 & 63 & 0.049 & 4.0 \\
\hline $\mathrm{Fe}\left(\mu \mathrm{g} \mathrm{g}^{-1}\right)$ & 173 & 158 & 166 & 0.419 & 10.9 \\
\hline $\mathrm{Zn}\left(\mu \mathrm{g} \mathrm{g}^{-1}\right)$ & 20 & 19 & 22 & 0.426 & 2.0 \\
\hline $\operatorname{Mn}\left(\mu \mathrm{g} \mathrm{g}^{-1}\right)$ & 198 & 150 & 142 & 0.011 & 14.9 \\
\hline $\mathrm{Cu}\left(\mu \mathrm{g} \mathrm{g}^{-1}\right)$ & 4.95 & 5.32 & 5.25 & 0.304 & 0.235 \\
\hline $\operatorname{Mo}\left(\mu g^{-1}\right)$ & 0.25 & 0.29 & 0.32 & 0.192 & 0.034 \\
\hline
\end{tabular}

s.e.d. $=$ standard error of difference between means

d.f. = degrees of freedom 
Table 5 The effect of soil incorporation of biochar from produced by slow pyrolysis of Castenea sativa at 0,20 or $50 \mathrm{t} \mathrm{ha}^{-1}$ on nutrient concentrations of potato tubers of the cultivar Maris Piper in late September at harvest

\begin{tabular}{|c|c|c|c|c|c|}
\hline \multirow[b]{2}{*}{ Nutrient } & \multicolumn{3}{|c|}{ Amount of biochar $\left(\mathrm{t} \mathrm{ha}^{-1}\right)$} & \multirow{2}{*}{$p$} & \multirow{2}{*}{$\begin{array}{l}\text { s.e.d. } \\
\text { (8 d.f.) }\end{array}$} \\
\hline & 0 & 20 & 50 & & \\
\hline$N\left(\mathrm{cg} \mathrm{g}^{-1}\right)$ & 1.13 & 1.07 & 1.05 & 0.74 & 0.093 \\
\hline $\mathrm{P}\left(\mathrm{cg} \mathrm{g}^{-1}\right.$ & 2318 & 2231 & 2203 & 0.69 & 136.1 \\
\hline $\mathrm{K}\left(\mathrm{cg} \mathrm{g}^{-1}\right)$ & 21207 & 21800 & 23076 & 0.09 & 748.4 \\
\hline $\operatorname{Mg}\left(\mathrm{cg} \mathrm{g}^{-1}\right)$ & 815 & 821 & 850 & 0.56 & 33.2 \\
\hline$S\left(\mathrm{cg} \mathrm{g}^{-1}\right)$ & 1008 & 946 & 953 & 0.56 & 61.0 \\
\hline $\mathrm{Ca}\left(\mathrm{cg} \mathrm{g}^{-1}\right)$ & 3.60 & 3.42 & 3.34 & 0.64 & 26.3 \\
\hline$B\left(\mu g g^{-1}\right)$ & 4.18 & 4.25 & 4.30 & 0.54 & 0.101 \\
\hline $\mathrm{Fe}\left(\mu \mathrm{g} \mathrm{g}^{-1}\right)$ & 52.2 & 46.7 & 44.4 & 0.46 & 6.12 \\
\hline $\mathrm{Zn}\left(\mu \mathrm{g} \mathrm{g}^{-1}\right)$ & 14.73 & 13.68 & 13.62 & 0.58 & 1.149 \\
\hline $\mathrm{Mn}\left(\mu \mathrm{g} \mathrm{g}^{-1}\right)$ & 7.77 & 6.93 & 6.87 & 0.24 & 0.539 \\
\hline $\mathrm{Cu}\left(\mu \mathrm{g} \mathrm{g}^{-1}\right)$ & 4.88 & 4.35 & 4.23 & 0.39 & 0.477 \\
\hline $\mathrm{N}: \mathrm{S}$ ratio & 11.05 & 11.25 & 11.03 & 0.78 & 0.337 \\
\hline
\end{tabular}

s.e.d. $=$ standard error of difference between means

d.f. $=$ degrees of freedom 
Table 6 The effect of soil incorporation of biochar produced by slow pyrolysis of Castenea sativa at 0,20 or $50 \mathrm{t} \mathrm{ha}^{-1}$ on the fruit size and yield per plant of first year strawberry plants of the cultivar Elsanta, where strawberries $>25 \mathrm{~mm}$ are marketable

\begin{tabular}{|c|c|c|c|c|c|c|}
\hline \multirow{2}{*}{ Fruit size $(\mathrm{mm})$} & & \multicolumn{3}{|c|}{ Amount of biochar $\left(\mathrm{t} \mathrm{ha}^{-1}\right)$} & \multirow{2}{*}{$p$} & \multirow{2}{*}{$\begin{array}{l}\text { s.e.d. } \\
\text { (8 d.f. }\end{array}$} \\
\hline & & 0 & 20 & 50 & & \\
\hline \multirow[t]{2}{*}{$>35$} & Number & 6.8 & 6.3 & 5.6 & 0.23 & 0.67 \\
\hline & Weight (g) & 141.9 & 129.6 & 120.7 & 0.39 & 14.64 \\
\hline \multirow[t]{2}{*}{$25-35$} & Number & 20.7 & 19.3 & 15.8 & 0.31 & 3.03 \\
\hline & Weight (g) & 220.8 & 200.8 & 163.3 & 0.17 & 27.82 \\
\hline \multirow[t]{2}{*}{$<25$} & Number & 5.9 & 5.5 & 5.5 & 0.83 & 0.76 \\
\hline & Weight (g) & 29.3 & 27.3 & 27.4 & 0.81 & 3.48 \\
\hline \multirow[t]{2}{*}{ Misshapes (waste) } & Number & 5.6 & 5.2 & 4.6 & 0.11 & 0.40 \\
\hline & Weight (g) & 119.8 & 106.3 & 84.1 & $<0.01$ & 7.26 \\
\hline \multirow[t]{2}{*}{ Damaged* } & Number & 8.6 & 10.2 & 6.8 & 0.06 & 1.10 \\
\hline & Weight (g) & 78.5 & 96.2 & 69.8 & 0.05 & 9.15 \\
\hline Total crop ${ }^{\mathrm{a}}$ & Number & 47.6 & 46.5 & 38.3 & & \\
\hline Total crop waste ${ }^{b}$ & & 14.2 & 15.4 & 11.4 & & \\
\hline Commercial crop ${ }^{(a-b)}$ & & 33 & 31 & 27 & & \\
\hline Total crop ${ }^{a}$ & Weight (g) & 590.3 & 560.2 & 465.3 & & \\
\hline Total crop waste ${ }^{b}$ & & 198.3 & 202.5 & 153.9 & & \\
\hline Commercial crop ${ }^{(a-b)}$ & & 392 & 358 & 311 & & \\
\hline
\end{tabular}

s.e.d. $=$ standard error of difference between means

d.f. $=$ degrees of freedom

*damaged has 6 d.f. 
Table 7 The effect of soil incorporation of biochar produced by slow pyrolysis of Castenea sativa at 0,20 or $50 \mathrm{t} \mathrm{ha}^{-1}$ on the fruit size and yield per plant of second year strawberry plants of the cultivar Elsanta, where strawberries $>25 \mathrm{~mm}$ are marketable

\begin{tabular}{|c|c|c|c|c|c|c|}
\hline \multirow{2}{*}{ Fruit Size (mm) } & & \multicolumn{3}{|c|}{ Amount of biochar $\left(\mathrm{t} \mathrm{ha}^{-1}\right)$} & \multirow{2}{*}{$p$} & \multirow{2}{*}{$\begin{array}{l}\text { s.e.d. } \\
\text { (6 d.f.) }\end{array}$} \\
\hline & & 0 & 20 & 50 & & \\
\hline \multirow[t]{2}{*}{$>35$} & Number & 5.6 & 4.7 & 7.0 & 0.41 & 1.58 \\
\hline & Weight (g) & 103.6 & 99.4 & 148.9 & 0.36 & 35.03 \\
\hline \multirow[t]{2}{*}{$25-35$} & Number & 32.2 & 30.3 & 30.1 & 0.96 & 7.85 \\
\hline & Weight (g) & 370.6 & 343.3 & 356.8 & 0.95 & 85.85 \\
\hline \multirow[t]{2}{*}{$<25$} & Number & 25.0 & 23.3 & 7.2 & 0.11 & 7.71 \\
\hline & Weight (g) & 197.2 & 188.7 & 40.2 & 0.17 & 79.62 \\
\hline \multirow[t]{2}{*}{ Misshapes (waste) } & Number & 4.3 & 3.9 & 2.4 & 0.37 & 1.25 \\
\hline & Weight (g) & 40.3 & 32.6 & 24.8 & 0.28 & 8.68 \\
\hline \multirow[t]{2}{*}{ Damaged } & Number & 8.7 & 8.6 & 6.2 & 0.07 & 0.95 \\
\hline & Weight (g) & 81.4 & 85.8 & 63.2 & 0.23 & 12.27 \\
\hline Total crop $^{\mathrm{a}}$ & Number & 75.8 & 70.8 & 52.9 & & \\
\hline Total crop waste ${ }^{b}$ & & 13.0 & 12.5 & 8.6 & & \\
\hline Commercial crop ${ }^{(a-b)}$ & & 71 & 58 & 44 & & \\
\hline Total crop ${ }^{\mathrm{a}}$ & Weight (g) & 790 & 750 & 634 & & \\
\hline Total crop waste ${ }^{b}$ & & 122 & 118 & 88 & & \\
\hline Commercial crop ${ }^{(a-b)}$ & & 671 & 632 & 546 & & \\
\hline
\end{tabular}

s.e.d. = standard error of difference between means

d.f. = degrees of freedom 


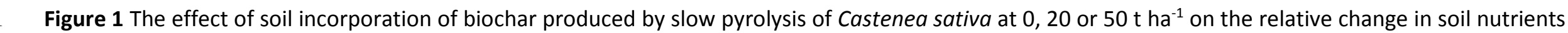
from the untreated treatment for plots of barley cultivar Westminster, strawberry cultivar Elsanta and potato cultivar Maris Piper. For each soil nutrient the $0 \mathrm{t} \mathrm{ha}^{-1}$ biochar treatment is expressed as 100 on the y axis. Standard errors of the mean are shown and are predicted by the Anova model based on the residual mean square.

Note: From fitting an ANCOVA model the significance of the trend lines is shown $(p<0.05 *, p<0.01 * *$ and $p<0.001 * * *)$
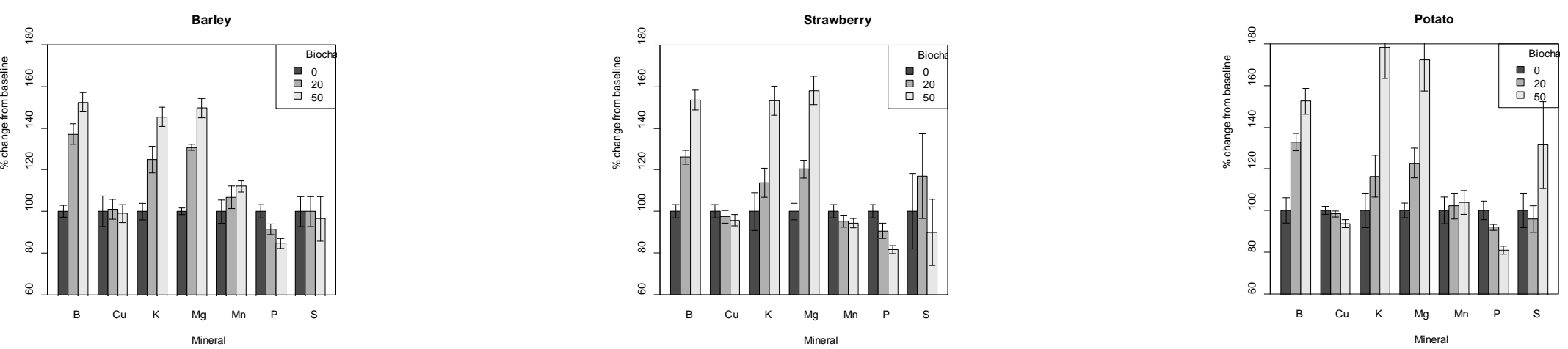

NS NS
NS ${ }^{* * *}{ }$ NS NS $^{* * *}{ }^{* * *}$ 
Figure 2 The effect of soil incorporation of biochar produced by slow pyrolysis of Castenea sativa at 0,20 or $50 \mathrm{t} \mathrm{ha}^{-1}$ on soil pH for the in plots of barley cultivar Westminster, strawberry cultivar Elsanta and potato cultivar Maris Piper. Standard errors of the mean are shown and are predicted by the Anova model based on the residual mean square.

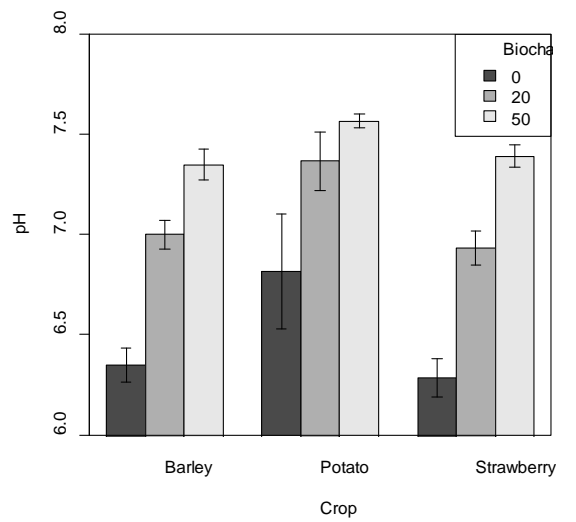

Note: From fitting an ANCOVA model all the slope are significant $p$ values (<0.001) different from zero 